\title{
Presence of langerhans cells, regulatory $T$ cells (Treg) and mast cells in asymptomatic apical periodontitis
}

\author{
Mariana Lobo BERGAMINI(a) \\ Andressa Pinto MARDEGAN(a) \\ Catharina Simioni DE ROSA ${ }^{(a)}$ \\ Michelle PALMIERI(a) \\ Dmitry José de Santana SARMENTO(a) \\ Karen Renata Nakamura HIRAKI(b) \\ André Luiz Ferreira COSTA ${ }^{(c)}$ \\ Bengt HASSÉUS(d) iD \\ Peter JONASSON(e) (DD \\ Paulo Henrique BRAZ-SILVA(a)
}

(a) Universidade de São Paulo - USP, School of Dentistry, Department of Stomatology, São

Paulo, SP, Brazil.

(b) Universidade Federal de Uberlândia - UFU, Institute of Biomedical Sciences, Department of Cell Biology, Histology and Embryology, Uberlândia, MG, Brazil.

(c) Universidade Cruzeiro do Sul - Unicsul, Postgraduate Program in Dentistry, São Paulo, SP, Brazil.

(d)Göteborgs Universitet - GU, The Sahlgrenska Academy, Institute of Odontology, Department of Oral Medicine and Pathology, Gothenburg, Sweden.

(e)Göteborgs Universitet - GU, The Sahlgrenska Academy, Institute of Odontology, Department of Endodontology, Gothenburg, Sweden.

Declaration of Interests: The authors certify that they have no commercial or associative interest that represents a conflict of interest in connection with the manuscript.

Corresponding Author:

Paulo Henrique Braz-Silva

E-mail: pbraz@usp.br

https://doi.org/10.1590/1807-3107bor-2020.vol34.0108

Submitted: October 8, 2019

Accepted for publication: July 10, 2020

Last revision: July 21, 2020
Abstract: Asymptomatic Apical Periodontitis is essentially an inflammatory disease of microbial aetiology. Association and function of the cell components involved, or specific inductive factors and growth mediators associated with development, maintenance and resolution of the periapical lesions are still unknown. The objective of this study was to evaluate the concentration of Regulatory $\mathrm{T}$ cells (FoxP3+; Treg), Langerhans cells (CD1a+; LC) and mast cells in asymptomatic apical periodontitis. 73 cases were selected: 30 periapical granulomas, 29 radicular cysts and 14 residual cysts. All groups were submitted to morphological analysis for classification of inflammatory infiltrate and thickness of the epithelial lining as well as to immunohistochemical analysis for detection of LC and Treg cells. Toluidine blue staining was used for detecting mast cells. Analysis showed higher mean numbers of LC $\left(8.2\right.$ cells $\left./ 0.2 \mathrm{~mm}^{2}\right)$, and Treg cells in radicular cysts $\left(5.910\right.$ cells $\left./ 0.2 \mathrm{~mm}^{2}\right)$. As for mast cells, it was found that radicular cysts had a higher mean number of these cells compared to other periapical lesions $\left(12.68\right.$ cells $\left./ 0.2 \mathrm{~mm}^{2}\right)$. The association between thickness of the epithelial lining and inflammatory cells showed that the presence of hypertrophic epithelium in radicular cysts presented higher density of LC. The number of LC and Treg cells play an important role in the control of the inflammatory micro-environment in periapical granulomas and radicular cysts, respectively. The presence of mast cells in radicular cysts may be associated with progression of the lesion. Knowledge regarding the inflammatory cell profile is therefore essential for a better understanding of the pathogenesis of asymptomatic periapical periodontitis.

Keywords: Periapical Periodontitis; T-Lymphocytes; Dendritic Cells; Mast Cells; Immunohistochemistry.

\section{Introduction}

Asymptomatic Apical Periodontitis is essentially an inflammatory disease of microbial aetiology. ${ }^{1,2}$ Despite the numerous experimental and clinical studies, one does not know exactly which associations and functions of the cell component are involved, nor specific inductive factors and growth mediators associated with development, maintenance and resolution of periapical lesions. ${ }^{3,4}$ 
The persistence of the inflammatory process is associated with bone resorption, which consequently results in replacement by granulation tissue, thus forming periapical granulomas, ${ }^{5}$ or inducing the proliferation of epithelial rests of Malassez, an event which can lead to the development of a radicular cyst. $5,6,7,8$ Distinct sub-populations of inflammatory cells have been described in periapical lesions, such as macrophages, mast cells, T cells, neutrophils and dendritic cells. ${ }^{78,9,10}$

The participation of mast cells in the pathogenesis of periapical lesions is not fully clarified and has been frequently related to allergic reactions (i.e. hypersensitivity).$^{11}$ The membrane of these cells contains IgE antibodies and the cytoplasm has metachromatic granules containing histamine, serotonin, heparin and proteases..$^{12}$ These mediators released after degranulation of mast cells play an important role in inflammation. ${ }^{13,14}$

Dendritic cells, especially the LC, have an important function in the cell-mediated immune reactions as well as in the pathogenesis of periapical lesions. ${ }^{3,15}$ These cells are responsible for presenting antigens to $\mathrm{T}$ cells and are also extremely important in the activation response of immune T- helper (Th) cells to Th1, Th2, Th17 or Treg cells. . $^{16,1718,19}$

Studies investigating the presence and function of regulatory $\mathrm{T}$ cells in asymptomatic periapical lesions are scanty in the literature. These cells are specialised T lymphocytes as they control the immune response by acting on the immune-tolerance mechanism to inhibit both proliferation and activity of $\mathrm{T}$ helper and cytotoxic T cells. ${ }^{20,21}$

Therefore, in the present study we have assessed the immunohistochemical expression of CD1a+ for $\mathrm{LC}$ and FoxP3+ Treg cells and also verified the presence of mast cells in periapical granulomas and radicular and residual cysts. In addition, we have assessed the number of FoxP3+, CD1a+ and mast cells in these lesions as well as correlated it to the intensity of inflammatory infiltrate and the thickness of the epithelial lining.

\section{Methodology}

This is a retrospective study in which 73 cases of asymptomatic apical periodontitis were selected, being 30 of periapical granulomas, 29 of radicular cysts and 14 of residual cysts. All cases were obtained from the archives of the Oral and Maxillofacial Surgical Pathology Service, Department of Stomatology, School of Dentistry, University of São Paulo. All procedures performed in our study were in accordance with human research ethical standards set by institutional and/or national research committees and with the 1964 Helsinki Declaration, including later amendments or comparable ethical standards. Informed consent was obtained from all individual participants included in the study. This study was approved by the research ethics committee of the School of Dentistry University of Sao Paulo, according to protocol number 2.135.164.

For morphological analysis, the haematoxylin/ eosin stained slides of each case were histologically re-evaluated by means of light microscopy to describe the major morphological aspects of each lesion. The inflammatory infiltrate was classified as mild, moderate or intense depending on the method adapted from Tsai et al. ${ }^{22}$ The thickness of the epithelial lining of radicular and residual cysts was defined as being atrophic (2 to 10 layers of cells and flat epithelial/ capsular border) or hyperplasic (> 10 layers of cells and corrugated epithelial/capsular border, often arranged in proliferative arches) considering the cyst's lining as a whole. ${ }^{23}$

Sections of $3 \mathrm{~mm}$ were cut and placed on glass slides before being stained in a solution of $1 \%$ toluidine blue solution (Dinâmica, São Paulo, São Paulo, Brazil) for 20 seconds and then washed in distilled water until the excess has been removed. The slides were mounted onto a SCA coverslipper apparatus (Tissue-Tel®, Sakura, Japan) for analysis with a light microscope (AxioScope ${ }^{\circledR}$, Carl Zeiss, Germany).

Immunohistochemical reactions were performed in $3 \mathrm{~mm}$ sections according to standardised procedures and by using the En-Vision Dual Link System kit (HRP®, Dako Cytomation ${ }^{\circledR}$, Carpinteria, USA) and diaminobenzidine as chromogenic agent. Antigens were recovered by using Tris-EDTA buffer solution at $\mathrm{pH} 8$ for FoxP3 and at $\mathrm{pH} 9$ for CD1a (Dako Cytomation ${ }^{\circledR}$, Carpinteria, USA). The primary antibody anti-FoxP3 (Clone 236/E7, Abcam, Cambridge, UK) was diluted at 1:200 ratio and 
incubated in humid chamber for 18 hours at $4^{\circ} \mathrm{C}$, whereas the anti-CD1a antibody (Flex Monoclonal Mouse Anti-Human, clone 010, ready-to-use [Link], DAKO Corporation, Carpinteria, USA) was diluted at 1:50 and incubated in humid chamber for 60 minutes at room temperature. Negative controls consisted of slides incubated with bovine serum albumin in place of the primary antibody. Sections of reactive lymph nodes were used as positive controls for immune-histochemical markers of inflammatory cells.

The slides were viewed with a light microscope (AxioScope ${ }^{\circledR}$, Carl Zeiss, Germany) by a single observer and cells positively immunolabelled for CD1a and FoxP3 antibodies, and mast cells stained with toluidine blue (Merck Sigma-Aldrich, Saint Louis, USA) were counted by using the hot spot technique. ${ }^{24}$ This technique consists in selecting the three most significant fields of the entire section and in counting the cells within these three fields at a 400x magnification. The final value is the average of these three counts and is expressed in number of cells $/ 0.2 \mathrm{~mm}^{2}$.

The results were analysed by using the SPSS software version 17.0 (SPSS, Inc. Chicago, USA). As the quantitative variables of this study had no normal distribution (Kolmogorov-Smirnov, $\mathrm{p}<0.05$ ), the Kruskal-Wallis test was used to compare the lesions regarding counts of cells marked by CD1a, FoxP3 and mast cells, time of evolution and size. Pearson's chi-square test was also used to analyse the qualitative variables (i.e. gender, symptoms, inflammatory infiltrate and thickness of the epithelial lining) of the lesions. A significance level of 5\% was adopted for all statistical tests.

\section{Results}

The patients' demographic and clinical data were obtained from surgical pathology records, thus some variables were missing and the overall value of each variable was specified in their descriptive analysis (Table 1). Radicular cysts were mostly observed among patients who were male $(55.2 \%$, $16 / 29$ ), and with mean age of $46.64 \pm 15.16$ years old, mean evolution time of $15 \pm 7.74$ months and $73.1 \%(19 / 26)$ of the cases being asymptomatic and measuring, on average, $16.45 \pm 11.87 \mathrm{~mm}$.

The majority of the residual cysts were mostly observed among patients who were male (58.3\%, 7/12), with half of the cases $(50 \%, 5 / 10)$ being asymptomatic. The mean age was $53.36 \pm 8.66$ years old and the mean evolution time was $16.88 \pm 19.65$ months, with the lesions measuring $28.10 \pm 19.80 \mathrm{~mm}$, on average.

Table 1. Demographic and clinical data.

\begin{tabular}{lccc}
\hline \multirow{2}{*}{\begin{tabular}{l} 
Variable \\
\cline { 2 - 3 } Sex
\end{tabular}} & Radicular cyst & Granuloma & $\mathrm{n}(\%)$ \\
Male & $\mathrm{n}(\%)$ & $\mathrm{n}(\%)$ & $7(58.3)$ \\
Female & $16(55.2)$ & $12(46.2)$ & $5(41.7)$ \\
Total & $13(44.8)$ & $14(53.8)$ & $12(100.0)^{*}$ \\
Color skin & $29(100.0)$ & $26(100.0)^{*}$ & \\
White & & & $4(44.4)$ \\
Black & $23(85.2)$ & $23(88.5)$ & $5(55.6)$ \\
Total & $4(14.8)$ & $3(11.5)$ & $9(100.0)^{*}$ \\
Symptomatology & $27(100.0)^{*}$ & $26(100.0)^{*}$ & \\
Asymptomatic & & & $5(50.0)$ \\
Symptomatic & $19(73.1)$ & $17(77.3)$ & $5(50.0)$ \\
Total & $7(26.9)$ & $22(100.0)^{*}$ & $10(100.0)^{*}$ \\
Total & $26(100.0)^{*}$ & $30(100.0)$ & $14(100.0)$ \\
\hline
\end{tabular}

${ }^{*}$ missing data. 
Periapical granulomas were mostly observed among patients who were female $(53.8 \%, 14 / 26)$, and asymptomatic $(77.3 \%, 17 / 22)$. The mean age was 47.32 \pm 20.71 years old and the mean evolution time was $38.31 \pm 40.18$ months, with the lesions measuring 11.71 $\pm 6.63 \mathrm{~mm}$, on average.

\section{Morphological assessment}

Morphological analysis showed that grade-III inflammatory infiltrate was commonly present in radicular cysts $(58.6 \%, 17 / 29)$ and periapical granulomas $(66.7 \%, 18 / 27)$. In residual cysts, grade-II inflammatory infiltrate was more frequent $(42.9 \%$, $6 / 14)$. There were no statistically significant differences (Pearson's chi-square test, $\mathrm{p}=0.104$ ).

Morphological analysis of the thickness of the epithelial lining revealed that radicular cysts mostly presented hypertrophic epithelium $(65.5 \%, 19 / 29)$, whereas residual cysts had a higher percentage of atrophic epithelium $(64.3 \%, 9 / 14)$. No statistically significant differences were found (Pearson's chi-square test $p=0.065$ ).

\section{Assessment of the number of CDlat, FoxP3+ and Mast cells}

Analysis of the immunohistochemical expression of anti-CD1a molecules showed that the mean numbers of CD1a+ cells were $8.16 \pm$ 2.60 cells $/ 0.2 \mathrm{~mm}^{2}$ in radicular cysts, $0.85 \pm 2.06$ cells/0.2 $\mathrm{mm}^{2}$ in periapical granulomas and 6.47 \pm 2.21 cells $/ 0.2 \mathrm{~mm}^{2}$ in residual cysts (Figure 1). Periapical granulomas had values lower than those of residual and radicular cysts (KruskalWallis test, $\mathrm{p}<0.001$ ) (Table 2).

As for anti-Fox-P3 antibody, on the other hand, analysis of the immunohistochemical analysis showed that the mean numbers of FoxP3+ cells were 5.91 \pm 2.58 cells $/ 0.2 \mathrm{~mm}^{2}$ in radicular cysts, $4.11 \pm 1.24$ cells $/ 0.2 \mathrm{~mm}^{2}$ in periapical granulomas and $5.30 \pm 2.46$ cells/0.2 mm² $(\mathrm{n}=14)$ in residual cysts (Figure 2). Periapical granulomas had values lower than those of residual and radicular cysts (Kruskal-Wallis test, $\mathrm{p}<0.044$ ) (Table 2).

Analysis of toluidine blue staining revealed that the mean numbers of stained mast cells were 12.68 \pm 6.78 cells $/ 0.2 \mathrm{~mm}^{2}$ in radicular cysts, $7.31 \pm 4.23$ cells $/ 0.2 \mathrm{~mm}^{2}$ in periapical granulomas and 5.42 \pm 3.55 cells $/ 0.2 \mathrm{~mm}^{2}$ in residual cysts (Figure 3). Radicular cysts had values higher than those of the other lesions $(p<0.001)$ (Table 2$)$.

\section{Assessment of the association between Inflammatory Infiltrate and Epithelial Lining Thickness and between Numbers of CDla+, FoxP3+ and Mast Cells}

Assessment of the association between inflammatory infiltrate and immunolabelling revealed that there was statistically significant difference

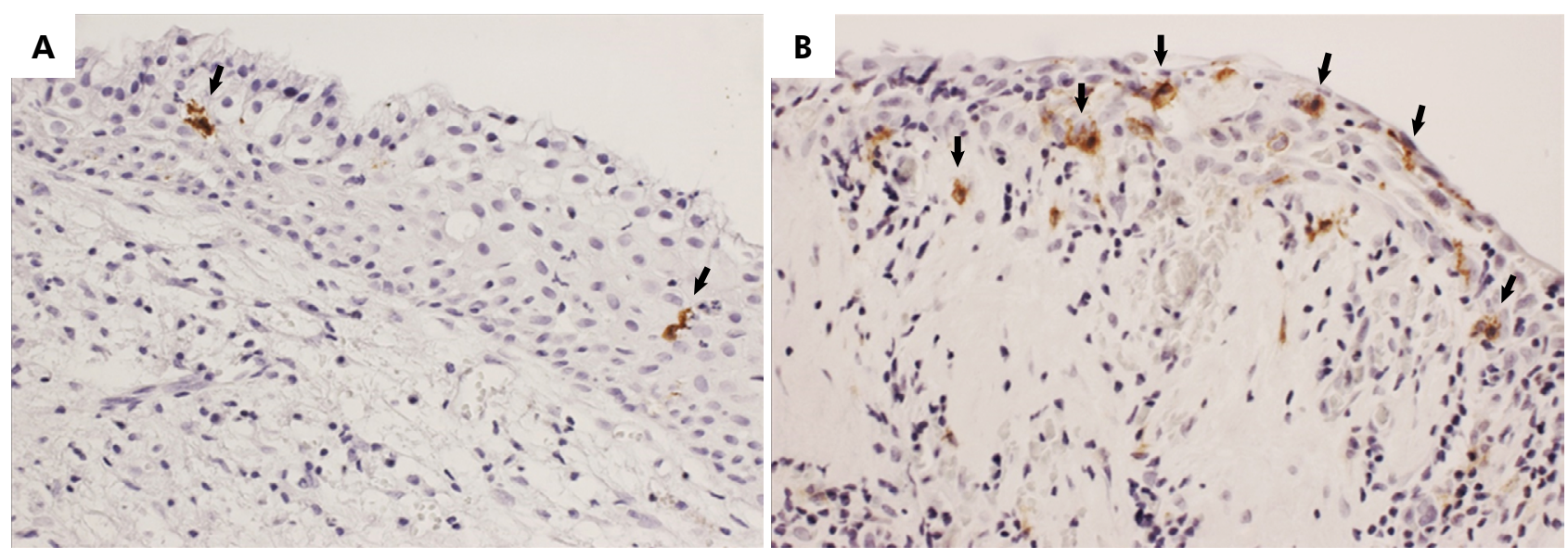

Figure 1. Langerhans Cells - Positive immunostaining for CDla (black arrows) in radicular cyst (A) and residual cyst (B) (original magnification: 400x). 
Table 2. Distribution of Langerhans cells (CDla), Treg cells (FoxP3) and mast cells in chronic apical periodontitis.

\begin{tabular}{|c|c|c|c|}
\hline Variables & $\mathrm{n}$ & Mean Rank & p-value* \\
\hline \multicolumn{4}{|l|}{ CDla } \\
\hline Radicular cyst & 29 & 53.71 & \\
\hline Periapical granuloma & 30 & 17.0 & $<0.001^{* *}$ \\
\hline Residual cyst & 14 & 45.25 & \\
\hline Total & 73 & & \\
\hline \multicolumn{4}{|l|}{ FoxP3 } \\
\hline Radicular cyst & 29 & 42.81 & \\
\hline Periapical granuloma & 29 & 29.33 & $0.044^{* *}$ \\
\hline Residual cyst & 14 & 38.39 & \\
\hline Total & 72 & & \\
\hline \multicolumn{4}{|l|}{ Mast cells } \\
\hline Radicular cyst & 29 & 49.07 & \\
\hline Periapical granuloma & 29 & 31.09 & $<0.001^{* *}$ \\
\hline Residual cyst & 14 & 21.68 & \\
\hline Total & 72 & & \\
\hline
\end{tabular}

*Kruskal-Wallis test; **Statistically significant.
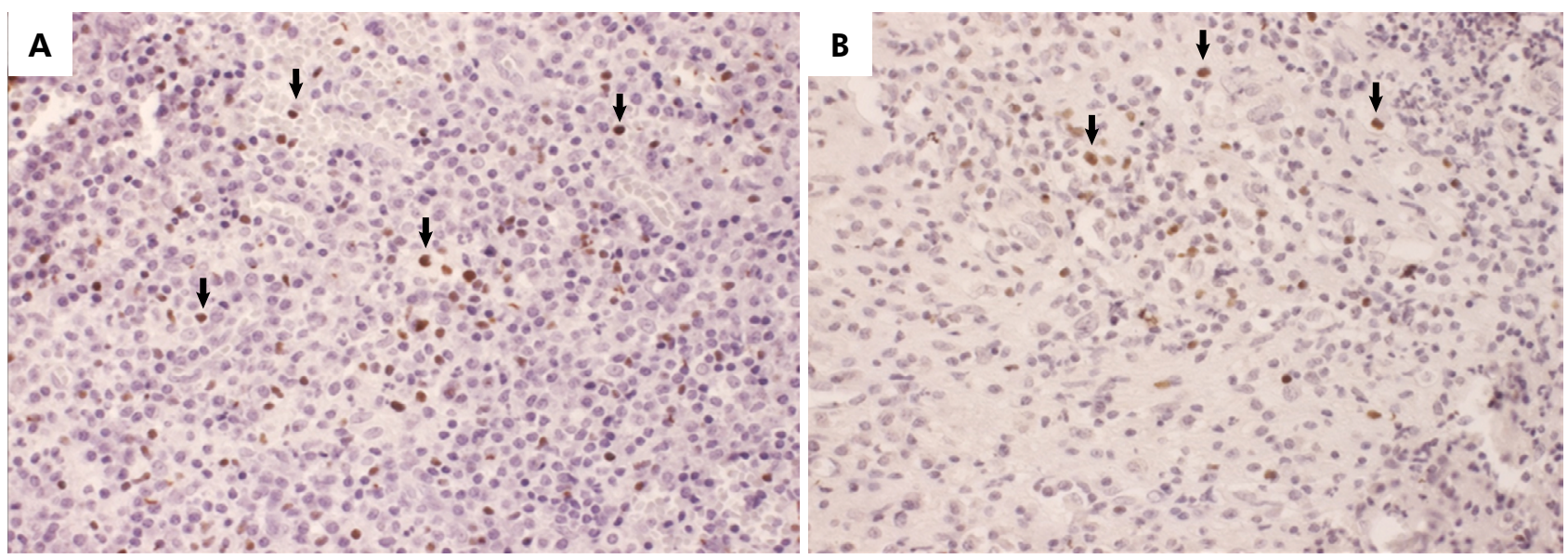

Figure 2. Regulatory T cells (Treg) - Positive immunostaining for FoxP3 (green arrows) in radicular cyst (A) and periapical granuloma (B) (original magnification: 400x).

regarding CD1a+ cells in periapical granulomas (Kruskal Wallis test, $\mathrm{p}<0.001$ ), since the number of $\mathrm{CD1a}+$ cells decreased as inflammatory infiltrate was more intense (Table 3).

The association between thickness of the epithelial lining and immunolabelling of these cells showed that the hypertrophic epithelium in radicular cysts had a higher density of CD1a+ cells compared to an atrophic epithelium in the same lesion (Mann-Whitney's test, p < 0.05) (Table 4).

\section{Discussion}

Asymptomatic apical periodontitis lesions develop from a chronic infection in the dental pulp ${ }^{25}$ and are histologically characterised by the presence of dense connective and granulation tissue infiltrated by different inflammatory cells. ${ }^{26}$ Among them, there are dendritic cells, T regulatory lymphocytes and mast cells, all antigen-presenting cells (APCs) playing a key role in the development and resolution of these lesions. ${ }^{4}$ 


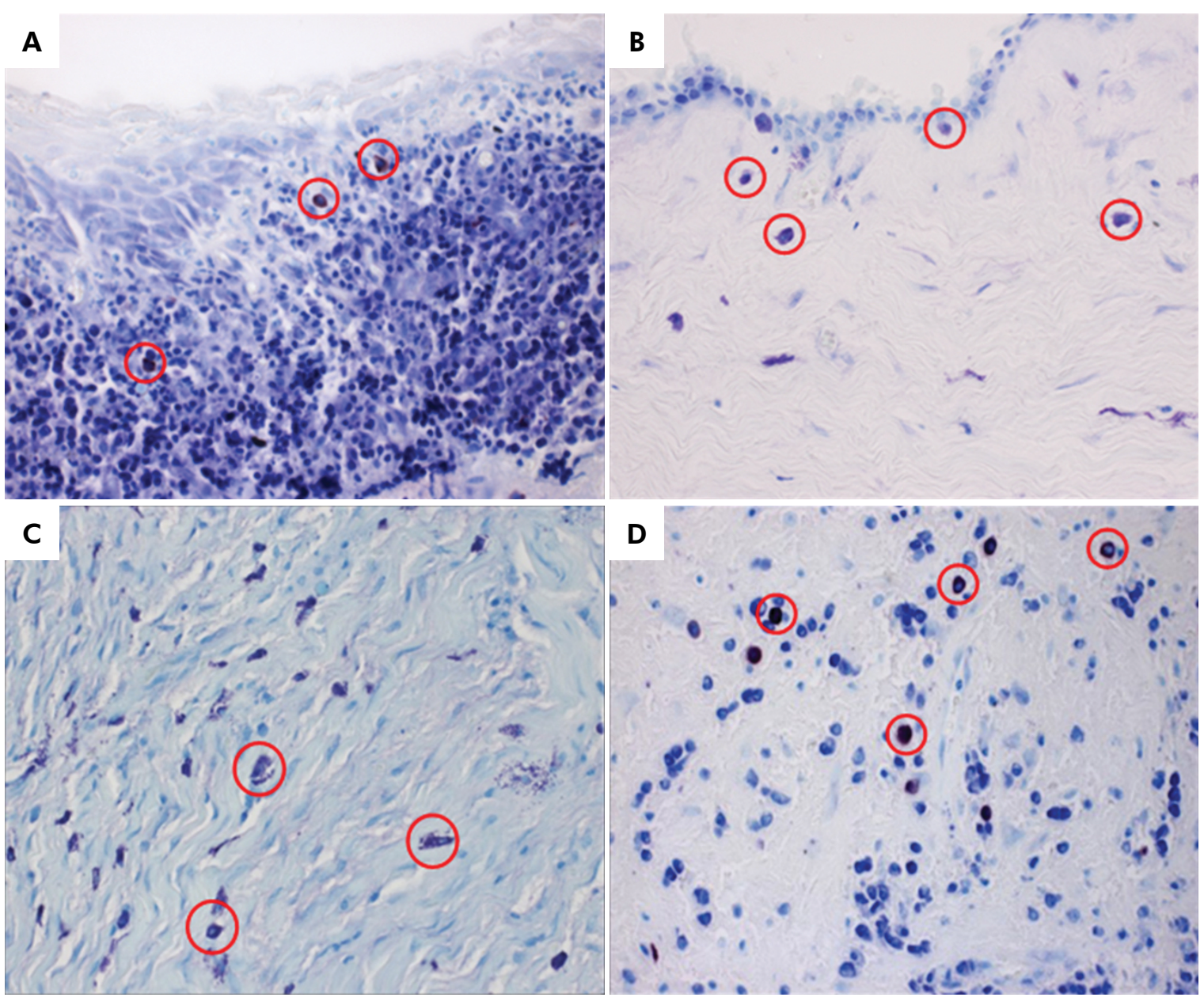

Figure 3. Mast cells - Toluidine blue staining for mast cells (red circles) in radicular cyst (A) (original magnification: 100x), residual cyst (B) and periapical granuloma (C e D) (original magnification: 400x)

Table 3. Correlation between inflammatory infiltrate and Langerhans cells (CDla), Treg cells (FoxP3) and mast cells in chronic apical periodontitis.

\begin{tabular}{lccccccccc}
\hline \multirow{2}{*}{ Inflammation } & \multicolumn{3}{c}{ Residual cyst } & \multicolumn{3}{c}{ Radicular cyst } & \multicolumn{2}{c}{ Periapical granuloma } \\
\cline { 2 - 10 } & $\mathrm{n}$ & Mean rank & $\mathrm{p}$-value* & $\mathrm{n}$ & Mean rank & $\mathrm{p}$-value* & $\mathrm{n}$ & Mean rank & $\mathrm{p}$-value* \\
\hline CD la & & & & & & & & & \\
I & 4 & 7.25 & & 4 & 13.25 & & 1 & 26.0 & \\
II & 6 & 8.83 & 0.506 & 8 & 16.19 & 0.845 & 8 & 19.25 & $<0.001^{* *}$ \\
III & 4 & 5.75 & & 17 & 14.85 & & 18 & 11.00 & \\
FoxP3 & & & & & & & & & \\
I & 4 & 6.25 & & 4 & 8.38 & & 1 & 26.0 & \\
II & 6 & 7.58 & 0.718 & 8 & 19.75 & 0.079 & 8 & 12.31 & 0.257 \\
III & 4 & 8.63 & & 17 & 14.32 & & 18 & 14.08 & \\
Mast cells & & & & & & & & & \\
I & 4 & 7.13 & & 4 & 9.63 & & 1 & 22.0 & \\
II & 6 & 7.83 & 0.963 & 8 & 13.44 & 0.243 & 8 & 11.06 & 0.311 \\
III & 4 & 7.38 & & 17 & 17.0 & & 18 & 14.86 & \\
\hline
\end{tabular}

*Kruskal-Wallis test; ${ }^{* *}$ Statistically significant. 
Table 4. Correlation between the thickness of the epithelial lining and Langerhans cells (CD1a), Treg cells (FoxP3) and mast cells in residual and radicular cysts.

\begin{tabular}{|c|c|c|c|c|c|c|}
\hline \multirow{2}{*}{ Inflammation } & \multicolumn{3}{|c|}{ Residual cyst } & \multicolumn{3}{|c|}{ Radicular cyst } \\
\hline & $\mathrm{n}$ & Mean Rank & $p$-value* & $\mathrm{n}$ & Mean Rank & $p$-value* \\
\hline \multicolumn{7}{|l|}{ CDla } \\
\hline Atrophic & 9 & 8.06 & \multirow{2}{*}{0.499} & 10 & 9.9 & \multirow{2}{*}{$0.018^{* *}$} \\
\hline Hypertrophic & 5 & 6.50 & & 19 & 17.68 & \\
\hline \multicolumn{7}{|l|}{ FoxP3 } \\
\hline Atrophic & 9 & 8.72 & \multirow{2}{*}{0.138} & 10 & 13.35 & \multirow{2}{*}{0.446} \\
\hline Hypertrophic & 5 & 5.30 & & 19 & 15.87 & \\
\hline \multicolumn{7}{|l|}{ Mast cells } \\
\hline Atrophic & 9 & 6.94 & \multirow{2}{*}{0.502} & 10 & 12.35 & \multirow{2}{*}{0.222} \\
\hline Hypertrophic & 5 & 8.50 & & 19 & 16.39 & \\
\hline
\end{tabular}

The mean numbers of CD1a+ cells in radicular cysts, periapical granulomas and residual cysts in the present study were, respectively, 8.16, 0.853 and 6.471 cells $/ 0.2 \mathrm{~mm}^{2}$, thus showing a significant association between LC and type of lesion. Santos et al. ${ }^{3}$ found similar results by reporting that $69.2 \%$ of the radicular cysts had CD1a+ cells. On the other hand, only 11.1\% of the periapical granulomas were positive for CD1a. ${ }^{3}$ However, LC count was not significant in the cases of periapical granulomas, which is contrary to the results reported by Suzuki et al. ${ }^{16}$

LC were found in all cases of radicular cysts, a finding also reported in the studies by Suzuki et al. ${ }^{16}$ and Carrillo et al. ${ }^{27}$ On the other hand, Piattelli et al. ${ }^{28}$ and Santos et al. ${ }^{3}$ detected no such cells in radicular cysts. This lower number of CD1a+ cells may be related to the migration of these cells to regional lymph nodes after their activation after contact with antigen ${ }^{29}$ or even by cellular apoptosis process after presentation of the antigen to CD4+ T cells. ${ }^{3}$

The association between inflammatory infiltrate and LC showed that the grade of inflammatory infiltration increases as the number of CD1a+ cells decreases in the periapical granulomas. This result suggests that immature dendritic cells play an important role in controlling the inflammatory process in periapical granulomas, since they are directly related to the process of immunological tolerance. ${ }^{30,31}$ For Santos et al., ${ }^{3}$ the intensity of inflammatory infiltrate is not only related to an increase in the amount of antigens in the lesion, but also to an exacerbated response of the individual's defence mechanism.

Suzuki et al. ${ }^{16}$ found a significant association between density of CD1a+ cells and epithelial proliferative potential in radicular cysts, residual cysts and epithelised granulomas. These cells were detected in epithelial components and sub-epithelial layers of the lining epithelium, with the majority of the cells being located in the intra-epithelial areas of the lesions. These results suggest that $\mathrm{LC}$ can reside in epithelial components, acting as a front-line agent against root canal antigens. ${ }^{16,32}$

In the present study, the association between the thickness of the epithelial lining and LC CD1a+ revealed that radicular cysts with hypertrophic epithelium presented higher cell density. The epithelial proliferative potential in residual cysts was much lower than in radicular cysts, which might be due to the lesion's chronicity and consequently to milder inflammatory changes According to some authors, the inflammatory stimulus provoked by growth factors and cytokines unchain the epithelial proliferation. 3,16,23

Analysis of the number of Treg cells (FoxP3+) showed a significantly greater amount of these cells in radicular cysts compared to periapical granulomas and residual cysts Marçal et al..$^{33}$ assessed the number of FoxP3+ cells in residual cysts and periapical granulomas and found no significant differences between these lesions. On the other hand, 
Peixoto et al. ${ }^{34}$ and Fukuda et al. ${ }^{17}$ found a higher number of FoxP3+ cells in periapical granulomas compared to radicular cysts. The authors suggest that Treg cells play an important role in modulating the inflammatory micro-environment in periapical lesions. ${ }^{17,34}$ These cells act as effector cells of the disease after receiving activation signals of stimulated LC. ${ }^{16,35}$

The results of the present study showed evidence of the relevance of Treg cells as they are an important factor in controlling the inflammatory microenvironment in radicular cysts. Different from other diseases, the root canal is a continuous antigenic source of several microorganisms in the periapical lesions. ${ }^{17}$ Therefore, in radicular cysts, it is suggested that epithelium plays a key role in the immune tolerance because it seems to express some cytokines on its layers, including dendritic cells, which are responsible for controlling the inflammatory process. ${ }^{16}$

The presence of mast cells was assessed by using the toluidine blue staining technique, which was shown to be very reliable for identification of granules of mast cells in periapical lesions. ${ }^{33,36,37}$ However, one limitation of this staining technique is its low sensitivity in detecting partially degranulated cells..$^{11,37}$ In this way, the number of mast cells may have been under-estimated in the present study.

Microscopic analysis of the number of mast cells revealed that these cells were more present in radicular cysts than in periapical granulomas and residual cysts This finding is consistent with those reported elsewhere, in which tryptase-positive cells were detected by using toluidine blue staining. ${ }^{11,37,38}$ These observations suggest that mast cells may play a key role in the pathogenesis of asymptomatic apical periodontitis, more notably in cysts. The presence of mast cells in radicular cysts may be associated with the lesion progression in terms of production of proteoglycans, angiogenic response, vasodilatation, synthesis of collagen, bone resorption, inflammatory regulation and increased cystic fluid. . $^{36,37,38}$
The recruitment of mast cells and consequent release of prostaglandins during degranulation may have a role in the bone resorption, thus promoting cyst growth. ${ }^{38}$ In addition, mast cells in asymptomatic periapical inflammatory lesions can act as antigen-presenting cells (APCs) for T cells. The activation of T cells would lead to the stimulation of mast cells and consequently to degranulation and release of cytokines (e.g. TNFa), resulting in pro-inflammatory and pro-secretory effects on these cells and other cellular types..$^{38}$

The main limitation of this retrospective study was the lack or the quality of clinical data of the lesions in part of the surgical pathology records.

\section{Conclusions}

Periapical granulomas with mild-moderate inflammatory infiltrate had a higher mean number of CD1a+ LC. This result suggests that LC play an important role in the control of inflammatory process in periapical granulomas, since these cells are directly related to the process of immune tolerance. Radicular cysts had a higher mean number of Treg cells (FoxP3+), thus evidencing the relevance of these cells as an important factor in the control of inflammatory micro-environment in radicular cysts. Mast cells were more commonly found in radicular cysts, indicating that these cells play a key role in their pathogenesis. The greater presence of mast cells in radicular cysts may be associated with the progression of the lesion.

\section{Acknowledgements}

This study was supported by grants from the Fundação de Amparo à Pesquisa do Estado deSão Paulo (FAPESP), according to protocol number 2015/07727-9 and from Coordenação de Aperfeiçoamento de Pessoal de Nível Superior (CAPES), according to protocol number 001.

\section{References}

1. Sunde PT, Tronstad L, Eribe ER, Lind PO, Olsen I. Assessment of periradicular microbiota by DNA-DNA hybridization. Endod Dent Traumatol. 2000 Oct;16(5):191-6. https://doi.org/10.1034/i.1600-9657.2000.016005191.x 
Bergamini ML, Mardegan AP, De Rosa CS, Palmieri M, Sarmento DJS, Hiraki KRN et al.

2. Nair PN. On the causes of persistent apical periodontitis: a review. Int Endod J. 2006 Apr;39(4):249-81. https://doi.org/10.1111/j.1365-2591.2006.01099.x

3. Santos LC, Ramos EA, Gurgel CA, Santana EJ, Santos JN. Immunohistochemical detection of Langerhans cells in dental granulomas and radicular cysts. J Mol Histol. 2007 Jun;38(3):201-5. https://doi.org/10.1007/s10735-007-9088-3

4. Colić M, Gazivoda D, Vucević D, Vasiliiić S, Rudolf R, Lukić A. Proinflammatory and immunoregulatory mechanisms in periapical lesions. Mol Immunol. 2009 Nov;47(1):101-13. https://doi.org/10.1016/i.molimm.2009.01.011

5. Costa Neto H, Andrade AL, Gordón-Núñez MA, Freitas RA, Galvão HC. Immunoexpression of tryptase-positive mast cells in periapical granulomas and radicular cysts. Int Endod J. 2015 Aug;48(8):729-35. https://doi.org/10.1111/iej.12366

6. Muglali M, Komerik N, Bulut E, Yarim GF, Celebi N, Sumer M. Cytokine and chemokine levels in radicular and residual cyst fluids. J Oral Pathol Med. 2008 Mar;37(3):185-9. https://doi.org/10.1111/j.1600-0714.2007.00595.x

7. Huang GT, Do M, Wingard M, Park JS, Chugal N. Effect of interleukin-6 deficiency on the formation of periapical lesions after pulp exposure in mice. Oral Surg Oral Med Oral Pathol Oral Radiol Endod. 2001 Jul;92(1):83-8. https://doi.org/10.1067/moe.2001.115025

8. Silva TA, Garlet GP, Lara VS, Martins W Jr, Silva JS, Cunha FQ. Differential expression of chemokines and chemokine receptors in inflammatory periapical diseases. Oral Microbiol Immunol. 2005 Oct;20(5):310-6. https://doi.org/10.1111/j.1399-302X.2005.00232.x

9. Bracks IV, Armada L, Gonçalves LS, Pires FR. Distribution of mast cells and macrophages and expression of interleukin-6 in periapical cysts. J Endod. 2014 Jan;40(1):63-8. https://doi.org/10.1016/i.joen.2013.09.037

10. Braz-Silva PH, Bergamini ML, Mardegan AP, Rosa CS, Hasseus B, Jonasson P. Inflammatory profile of chronic apical periodontitis: a literature review. Acta Odontol Scand. 2019 Apr;77(3):173-80. https://doi.org/10.1080/00016357.2018.1521005

11. Drazić R, Sopta J, Minić AJ. Mast cells in periapical lesions: potential role in their pathogenesis. J Oral Pathol Med. 2010 Mar;39(3):257-62. https://doi.org/10.1111/i.1600-0714.2009.00870.x

12. Torabinejad M, Kettering JD, Bakland LK. Localization of IgE immunoglobulin in human dental periapical lesions by the peroxidase-antiperoxidase method. Arch Oral Biol. 1981;26(8):677-81. https://doi.org/10.1016/0003-9969(81)90165-5

13. Andrade AL, Nonaka CF, Gordón-Núñez MA, Freitas RA, Galvão HC. Immunoexpression of interleukin 17, transforming growth factor $\beta 1$, and forkhead box P3 in periapical granulomas, radicular cysts, and residual radicular cysts. J Endod. 2013 Aug;39(8):990-4. https://doi.org/10.1016/i.joen.2013.04.028

14. Mekori YA, Metcalfe DD. Mast cell-T cell interactions. J Allergy Clin Immunol. 1999 Sep;104(3 Pt 1):517-23. https://doi.org/10.1016/S0091-6749(99)70316-7

15. Romagnoli P. Dendritic cells in the skin and mucosa: what's new. J Eur Acad Dermatol Venereol. 2001 Mar;15(2):110-1. https://doi.org/10.1046/j.1468-3083.2001.00224.x

16. Suzuki T, Kumamoto H, Ooya K, Motegi K. Immunohistochemical analysis of CDla-labeled Langerhans cells in human dental periapical inflammatory lesions_correlation with inflammatory cells and epithelial cells. Oral Dis. 2001 Nov;7(6):336-43. https://doi.org/10.1034/j.1601-0825.2001.00722.x

17. Fukada SY, Silva TA, Garlet GP, Rosa AL, Silva JS, Cunha FQ. Factors involved in the Thelper type 1 and type 2 cell commitment and osteoclast regulation in inflammatory apical diseases. Oral Microbiol Immunol. 2009 Feb;24(1):25-31. https://doi.org/10.1111/j.1399-302X.2008.00469.x

18. Ihan Hren N, Ihan A. T lymphocyte activation and cytokine expression in periapical granulomas and radicular cysts. Arch Oral Biol. 2009 Feb;54(2):156-61. https://doi.org/10.1016/i.archoralbio.2008.09.014

19. Colić M, Gazivoda D, Vucević D, Majstorović I, Vasilijić S, Rudolf R, et al. Regulatory T-cells in periapical lesions. J Dent Res. 2009 Nov;88(11):997-1002. https://doi.org/10.1177/0022034509347090

20. Beyer M, Schultze JL. Regulatory T cells: major players in the tumor microenvironment. Curr Pharm Des. 2009;15(16):1879-92. https://doi.org/10.2174/138161209788453211

21. Vignali DA, Collison LW, Workman CJ. How regulatory T cells work. Nat Rev Immunol. 2008 Jul;8(7):523-32. https://doi.org/10.1038/nri2343

22. Tsai CH, Weng SF, Yang LC, Huang FM, Chen YJ, Chang YC. Immunohistochemical localization of tissue-type plasminogen activator and type I plasminogen activator inhibitor in radicular cysts. J Oral Pathol Med. 2004 Mar;33(3):156-61. https://doi.org/10.1111/i.0904-2512.2004.00133.x

23. Moreira PR, Santos DF, Martins RD, Gomez RS. CD57+ cells in radicular cyst. Int Endod J. 2000 Mar;33(2):99-102. https://doi.org/10.1046/j.1365-2591.2000.00276.x

24. Braz-Silva PH, Vitale S, Butori C, Guevara N, Santini J, Magalhães M, et al. Specific infiltration of langerin-positive dendritic cells in EBV-infected tonsil, Hodgkin lymphoma and nasopharyngeal carcinoma. Int J Cancer. 2011 May;128(10):2501-8. https://doi.org/10.1002/ijc.25597

25. Colic M, Gazivoda D, Vasilijic S, Vucevic D, Lukic A. Production of IL-10 and IL-12 by antigen-presenting cells in periapical lesions. J Oral Pathol Med. 2010 Oct;39(9):690-6. https://doi.org/10.1111/j.1600-0714.2010.00925.x 
- Presence of langerhans cells, regulatory T cells (Treg) and mast cells in asymptomatic apical periodontitis

26. Lukić A, Danilović V, Petrović R. [Comparative immunohistochemical and quantitative analysis of inflammatory cells in symptomatic and asymptomatic chronic periapical lesions]. Vojnosanit Pregl. 2008 Jun;65(6):435-40. Serbian. https://doi.org/10.2298/VSP0806435L

27. Carrillo C, Peñarrocha M, Peñarrocha M, Vera F, Peñarrocha D. Immunohistochemical study of Langerhans cells in periapical lesions: correlation with inflammatory cell infiltration and epithelial cell proliferation. Med Oral Patol Oral Cir Bucal. 2010 Mar;15(2):e335-9. https://doi.org/10.4317/medoral.15.e335

28. Piattelli A, Rubini C, lezzi G, Fioroni M. CDla-positive cells in odontogenic cysts. J Endod. 2002 Apr;28(4):267-8. https://doi.org/10.1097/00004770-200204000-00001

29. Séguier S, Godeau G, Leborgne M, Pivert G, Brousse N. Quantitative morphological analysis of Langerhans cells in healthy and diseased human gingiva. Arch Oral Biol. 2000 Dec;45(12):1073-81. https://doi.org/10.1016/S0003-9969(00)00069-8

30. Mutyambizi K, Berger CL, Edelson RL. The balance between immunity and tolerance: the role of Langerhans cells. Cell Mol Life Sci. 2009 Mar;66(5):831-40. https://doi.org/10.1007/s00018-008-8470-y

31. Gabrilovich D. Mechanisms and functional significance of tumour-induced dendritic-cell defects. Nat Rev Immunol. 2004 Dec;4(12):941-52. https://doi.org/10.1038/nri1498

32. Lombardi T, Hauser C, Budtz-Jörgensen E. Langerhans cells: structure, function and role in oral pathological conditions. J Oral Pathol Med. 1993 May;22(5):193-202. https://doi.org/10.1111/j.1600-0714.1993.tb01056.x

33. Marçal JR, Samuel RO, Fernandes D, Araujo MS, Napimoga MH, Pereira SA, et al. T-helper cell type 17/regulatory T-cell immunoregulatory balance in human radicular cysts and periapical granulomas. J Endod. 2010 Jun;36(6):995-9. https://doi.org/10.1016/j.joen.2010.03.020

34. Peixoto RF, Pereira JS, Nonaka CF, Silveira EJ, Miguel MC. Immunohistochemical analysis of FoxP3+ cells in periapical granulomas and radicular cysts. Arch Oral Biol. 2012 Sep;57(9):1159-64. https://doi.org/10.1016/i.archoralbio.2012.02.005

35. Contos JG, Corcoran JF Jr, LaTurno SA, Chiego DJ Jr, Regezi JÁ. Langerhans cells in apical periodontal cysts: an immunohistochemical study. J Endod. 1987 Feb;13(2):52-5. https://doi.org/10.1016/S0099-2399(87)80154-1

36. Ledesma-Montes C, Garcés-Ortíz M, Rosales-García G, Hernández-Guerrero JC. Importance of mast cells in human periapical inflammatory lesions. J Endod. 2004 Dec;30(12):855-9. https://doi.org/https://doi.org/10.1097/01.DON.0000134207.67360.FC

37. Fonseca-Silva T, Santos CC, Alves LR, Dias LC, Brito M Jr, Paula AM, et al. Detection and quantification of mast cell, vascular endothelial growth factor, and microvessel density in human inflammatory periapical cysts and granulomas. Int Endod J. 2012 Sep;45(9):859-64. https://doi.org/10.1111/j.1365-2591.2012.02043.x

38. Rodini CO, Batista AC, Lara VS. Comparative immunohistochemical study of the presence of mast cells in apical granulomas and periapical cysts: possible role of mast cells in the course of human periapical lesions. Oral Surg Oral Med Oral Pathol Oral Radiol Endod. 2004 Jan;97(1):59-63. https://doi.org/10.1016/S1079-2104(03)00378-0 